\title{
İvermektinin Küçük Ruminant Vebası (PPR) Virusuna Karşı In Vitro Antiviral Etkinliği
}

\author{
• Eda Baldan TOKER ${ }^{1}, \oplus$ Özer ATEŞ ${ }^{1}, \oplus$ Kadir YEŞíLBAĞ ${ }^{1 *}$
}

1 Bursa Uludağ Üniversitesi, Veteriner Fakültesi, Viroloji Anabilim Dalı, 16059 Bursa, Türkiye

Received 15-10-2021 Accepted 17-12-2021

\section{Özet}

Küçük ruminant vebası (PPR), koyun ve keçi yetiştiriciliğinde önemli ekonomik kayıplara neden olan ve Dünya Hayvan Sağllğı Örgütü tarafından bildirimi zorunlu hastalıklar listesinde yer alan bir hastalıktır. Hastalığı kontrol altında tutmanın en etkili çözümü aşı uygulamaları olsa da enfeksiyon ortaya çıktığında Küçük ruminant vebası virusuna (PPRV) doğrudan etki gösteren bir antiviral ilaç bulunmamaktadır. Nematodlara karşı uygulanan geniş spektrumlu bir antiparaziter ajan olan ivermektinin (IVM) son yıllarda çeşitli viruslara karşı in vitro antiviral aktiviteye sahip olduğu bildirilmiştir. Bu çalışmada, PPRV'nin hücreye tutunma, giriş ve replikasyon aşamalarında IVM’nin antiviral aktivitesinin değerlendirilmesi amaçlanmıștır. Vero hücrelerinde IVM’nin viral replikasyon aşamasındaki etkinliğini değerlendirmek için IVM ile muamele edilmeyen ve non-sitotoksik IVM konsantrasyonları (1,0 ve 2,5 $\mu \mathrm{M})$ ile tedavi edilen PPRV'nin viral titreleri enfeksiyon sonrası 8 gün boyunca karşılaştırıldı. 2,5 MM IVM varlığında PPRV’nin replikasyon aşamasında ortalama viral titre değerlerinde 1,12 log10 DKID50/0,1ml düzeyinde düşüş ile önemli oranda azalma görüldü $(\mathrm{P}<0,05)$. Hücreye tutunma ve giriş aşamalarında IVM'nin PPRV’ye karşı antiviral aktivitesini değerlendirmek amacıyla IVM ile muamele edilmeyen ve 2,5 $\mu \mathrm{M}$ IVM ile muamele edilen virusun viral titreleri, virus ekimini takiben 7 . günde virus titrasyon testi kullanılarak karşılaştırıldı. Testler sonucunda hücreye tutunma aşamasında viral titrede bir değişiklik saptanmazken, hücreye giriş (penetrasyon) aşaması testlerinde viral titre değerinde $0,37 \log _{10} \mathrm{DKID}_{50} / 0,1 \mathrm{ml}$ düzeyinde bir düşüş belirlendi. PPRV’nin 2,5 $\mu \mathrm{M}$ IVM ile muamelesi sonucunda enfeksiyöz virionların inhibisyon oranları viral replikasyon aşamasında \%92,50 ve hücreye giriş aşamasında \%57,83 olarak belirlenirken hücreye tutunma aşamasında herhangi bir etkisinin olmadığ $(\% 0,00)$ tespit edildi. Elde edilen veriler doğrultusunda, IVM'nin antiviral etkinliğinin PPRV çoğalma siklusunun geç aşamalarında daha etkili olduğu öngörülmektedir. Bu çalışma, IVM'nin PPRV'yi inhibe edebildiğini ve IVM’nin bir anti-PPRV ilacı olma potansiyeline sahip olabileceğini göstermiştir.

Anahtar kelimeler: İvermektin, Antiviral etkinlik, İn vitro test, Küçük ruminant vebası virusu, PPR

\section{In Vitro Antiviral Efficacy of Ivermectin against Peste des Petits Ruminants (PPR) Virus}

\section{Abstract}

Peste des petits ruminants (PPR) cause significant economic losses in sheep and goat breeding and are listed as notifiable diseases by the World Animal Health Organization. Although vaccination is the most effective solution for the control of PPR, there is no antiviral drug that directly affects the PPR virus (PPRV). In recent years, Ivermectin (IVM), a broad-spectrum antiparasitic, has also shown in vitro antiviral activity against several viruses. In this study, we aimed to investigate the antiviral efficacy of IVM at the stages of viral replication, cell-attachment and cell-entry of PPRV. To evaluate the efficacy of IVM at the viral-replication stage in Vero cells, the viral titers of PPRV infected cultures treated with non-cytotoxic IVM concentrations $(1.0$ and $2.5 \mu \mathrm{M})$ were compared to titers from PPRV infected cultures without IVM by virus titration assay for eight days. In the presence of $2.5 \mu \mathrm{M}$ IVM, the mean viral titers at the virus replication stage were significantly reduced by $1.12 \log _{10} \mathrm{TCID}_{50} / 0.1 \mathrm{ml}(\mathrm{P}<0.05)$. To evaluate the antiviral activity of IVM against PPRV at the cell-attachment and penetration stages, the virus titers of the untreated virus and virus treated with $2.5 \mu \mathrm{M}$ IVM were compared by virus titration assay on day 7 post-infection. As a result of the assays, no change in the viral titer was detected at the cell-attachment, while a decrease in viral titer of $0.37 \log _{10} \mathrm{TCID}_{50} / 0.1 \mathrm{ml}$ was detected in the penetration stage. As a result of treatment of PPRV infected cells with $2.5 \mu \mathrm{M}$ IVM, the inhibition rates of infectious virions were determined to be $92.50 \%$ in the viral replication, $57.83 \%$ in the penetration, and $0.00 \%$ in the cell-attachment stages. Consequently, the antiviral activity of IVM is predicted to be more effective in the late stages of the PPRV replication. This study has demonstrated that IVM can inhibit PPRV replication and may be a potential drug for PPR.

Keywords: Ivermectin; Antiviral efficiency; In vitro testing, Peste des petits ruminants virus, PPR

* Corresponding author: Kadir Yeşilbağ, kyesilbag@uludag.edu.tr, +090 2242941295 


\section{Giriş}

Küçük ruminant vebası (PPR), Dünya Hayvan Sağlığı Örgütü’nün (OIE) bildirimi zorunlu hastalıklar listesinde yer alan ve esas olarak koyun ve keçileri etkileyen oldukça bulaşıcı bir viral hastalıktır. İlk olarak 1942 yılında Fildişi Sahili’nde rapor edilen hastalık uzun yıllar bu bölge çevresinde sınırlı kalmıştır. Takiben Batı Afrika bölgesi sınırını aşarak birçok ülkede hastalık görülmeye başlamış ve son 15 yılda ise Asya, Afrika ve Orta Doğu bölgelerindeki 70'e yakın ülkede yaygınlığı giderek artarak 2016 yılında Gürcistan'da rapor edilmiştir. Hastalık, küçükbaş hayvan yetiștiriciliği yapılan bölgelerde önemli ekonomik kayıplara ve ciddi salgınlara neden olmaktadır ${ }^{1}$. Dünya genelinde PPR nedeniyle yılda yaklaşık 38 milyon küçükbaş hayvan ölümü meydana gelmekte ve PPR mortalitesinden kaynaklanan ekonomik kayıp değeri yılda ortalama 1,475 milyon Amerikan dolarına ulaşmaktadır². Bu nedenle gerçekleştirilen fayda-maliyet analizleri sonucunda, hastalığın 2030 yılına kadar ortadan kaldırılmasına yönelik OIE ve Birleşmiş Milletler Gıda ve Tarım Örgütü (FAO) tarafından eradikasyon kampanyası başlatılmıştır³.

Küçük ruminant vebası virusu (PPRV) Paramyxoviridae ailesindeki Morbillivirus cinsinin bir üyesi olmakla birlikte aynı cinste yer alan sığır vebası, köpek gençlik hastalığı ve kızamık virusları ile antijenik benzerlik göstermektedir ${ }^{4}$ Etkenin füzyon $(\mathrm{F})$ proteini ve nükleoprotein $(\mathrm{N})$ gen bölgelerinin kısmi sekans analizlerine göre 4 farklı soyu (lineage I-IV) tanımlanmıştır ${ }^{5}$. PPRV zarflı bir viriona ve tek iplikçikli RNA genomuna sahiptir. Viral replikasyon enfekte hücrelerin sitoplazmasında gerçekleșir ve olgun viruslar tomurcuklanma ile hücre dışına saçllır ${ }^{6}$. Enfekte hayvanlarda akut seyir izleyen hastalık tablosu yüksek ateş, göz ve burun akıntısı, stomatitis, şiddetli enteritis ve bronkopnöymoni ile karakterizedir ${ }^{7}$. Hastalık etkeni enfekte hayvanlarda immunsupresyona neden olarak özellikle pasteurellozis gibi sekonder bakteriyel enfeksiyonların ortaya çıkmasına ve hastalık seyrinin daha da ağırlaşmasına neden olmaktadır8. Hastalık endemik bölgelerde aşılama ile kontrol altına alınmaktadır. Aşı uygulamaları sonucunda hayvanlar uzun süreli bağışıklık geliştirir. PPR vakalarında, sekonder bakteriyel ve paraziter enfeksiyonları önlemek amaciyla destekleyici tedavilerin yapılması duyarlı bir popülasyonda \%100'e ulaşabilen ölüm oranlarını azaltabilir ${ }^{1}$. Ancak, PPR için doğrudan tedaviyi hedefleyen mevcut bir antiviral ilaç bulunmamaktadır.

İvermektin (IVM), avermektin B1'in kimyasal olarak değiştirilmiş bir türevidir ${ }^{10}$. Günümüzde nematodlara karşı uygulanan geniş spektrumlu bir antiparaziter ajan olarak kullanılmaktadır. Son yıllarda ivermektinin çeșitli viruslara karşı in vitro antiviral aktiviteye sahip olduğu da bildiril- miştir. İlk olarak, IVM'nin insan immun yetmezlik virusu tip 1 (HIV-1)'in integraz proteini ile bu proteinin çekirdeğe taşınmasından sorumlu olan importin $\alpha / \beta$ arasında inhibitör görevi gördüğü bildirilmiştir ${ }^{11}$. Daha sonra, IVM'nin konak hücrenin sinyal ve taşıma işlemlerinden sorumlu olan importin $\alpha / \beta$ aracılı nükleer lokalizasyon sinyalinin inhibisyonu aracılığıyla viral proteinlerin konakçı çekirdeğine taşınmasını engellediği gösterilmiştir ${ }^{12}$. Bu veriler 1ş1ğında, IVM'nin birçok RNA virusu (HIV-1, Batı Nil virusu, dang humması virusu, zika virusu, tick-borne encephalitis virusu, bovine viral diarrhea virusu, şap virusu, newcastle hastalığ 1 virusu, bovine respiratorik sinsitial virus, bovine parainfluenza virus tip 3, bovine coronavirus ve SarsCoV-2) ${ }^{12-18}$ ve DNA virusuna (yalancı kuduz virusu ve bovine herpesvirus tip 1) ${ }^{18-20}$ karşı antiviral etkinliğe sahip olduğu rapor edilmiştir. Bu çalışmanın amacı, PPRV’nin viral replikasyon, hedef hücreye tutunma (adsorbsiyon) ve hücreye giriş (penetrasyon) aşamalarında IVM’nin potansiyel antiviral etkinliğinin in vitro koşullarda değerlendirilmesidir.

\section{Materyal ve Metot İvermektin bileşimi}

Antiviral etkinliğin değerlendirilmesi amacıyla içeriğinde aktif bileșen olarak ivermektin $(10 \mathrm{mg} / \mathrm{ml})$ ihtiva eden enjeksiyonluk çözelti kullanıldı. Bu çözelti, 22.23-dihidro-avermektin B-1a ( 80\%) ve 22.23-dihidro-avermektin B-1b ( \%20) komponentlerini içermektedir (Avromec, Topkim, Türkiye). IVM stok solüsyonu Dulbecco Modified Eagle's Medium (DMEM) (Sigma, D7777, ABD) içerisinde 1000 $\mu \mathrm{M}$ IVM ihtiva edecek şekilde en az 10 dakika boyunca vortekslenerek hazırlandı.

\section{Hücre külttürü ve virus}

IVM'nin antiviral etkinliği PPRV-Nigeria 75/1 suşuna karş1 değerlendirildi. Stok virusun \%50 doku kültürü enfeksiyöz dozu $\left(\mathrm{DKID}_{50}\right) 5,25 \log _{10} \mathrm{DKID}_{50} / 0,1 \mathrm{ml}$ olarak hesapland. Stok virusun üretimi ve virus titrelerinin belirlenmesi aşamalarında Afrika yeşil maymun böbrek hücre hattı (Vero) kullanıldı. Hücrelerin hazırlanma aşamasında \%10 fötal dana serumu (FDS) (PAA, A11-151, Avusturya) ilave edilen DMEM kullanıldı ve hücreler $37^{\circ} \mathrm{C}$ ye ayarlı ve $\% 5 \mathrm{CO}_{2}$ içeren ortamda inkübe edildi. Ayrıca kültürlerde muhtemel mantar ve bakteri kontaminasyonunu önlemek amacryla DMEM içerisine $250 \mu \mathrm{l} / \mathrm{ml}$ Amfoterisin B ve $100 \mathrm{UI} /$ $\mathrm{ml}$ Streptomisin/Penisilin solüsyonları eklendi.

\section{Hücre canlılık testi}

IVM'nin sitotoksisite değerlerinin belirlenmesi amaciyla ilk olarak 24 gözlü pleytler Vero hücreleri $\left(8 \times 10^{4}\right.$ hücre $\left./ \mathrm{ml}\right)$ ile kaplandı. Pleytler yukarıda belirtilen koşullar altında 24 
saat boyunca inkübe edildi. Bu süre sonunda, hücre üst s1vısı uzaklaştırıldı ve hücrelerin üzerine 0,$0 ; 1,0 ; 2,5 ; 5,0 ; 7,5$ ve 10,0 $\mu \mathrm{M}$ konsantrasyonlarında IVM içeren $1 \mathrm{ml}$ DMEM eklendi ve pleytler aynı koşullar altında 8 gün boyunca takip edildi. Her 24 saatte bir (24, 48, 72, 96, 120, 144, 168 ve 192. saatlerde) hücre üst sıvıları, ilgili test gözlerinden uzaklaştırıldı ve hücreler tripsinizasyon aracılığıyla ayrıștırılarak santrifüj tüplerinde toplandı. Tüpler 1200 rpm'de 10 $\mathrm{dk}$ santrifüj edildi ve hücre peletleri $1 \mathrm{ml}$ DMEM içerisinde pipete edildi. Son olarak, \%0,4 tripan mavisi ile boyanan Vero hücreleri mikroskop altında incelenerek ve canlı hücrelerin toplam hücre sayısına bölünmesiyle hücre canlılık oranları yüzdesel olarak hesapland $\mathbf{1}^{18}$.

\section{İvermektinin PPRV replikasyonuna karşı antiviral et- kinliğinin belirlenmesi}

IVM'nin PPRV replikasyonu üzerindeki etkisini değerlendirmek için IVM ile muamele edilen ve edilmeyen virusla enfekte Vero hücrelerindeki viral titre değerleri karşılaşt1rıldı. Başlangıçta, 24 gözlü pleytler Vero hücreleri (8x104 hücre/ml) ile monolayer olarak kaplandı. Hücreler pleyt yüzeyinin \%80’ini kapladığında (yaklaşık 24 saat sonra) hücre üst sıvısı uzaklaştırıldı. Daha sonra, her bir gözdeki hücrelere $100 \mathrm{DKID}_{50}$ oranında sulandırılmış $200 \mu \mathrm{l}$ virus süspansiyonu inokule edildi ve pleytler iki saat süreyle inkübe edildi. Bu amaçla, 24 gözlü pleytler dikey pozisyonda kullanıldı ve ilk üç sütunu sitotoksik olmayan IVM konsantrasyonlarını test etmek için virusla enfekte edildi. Buna karşılık, sağlıklı hücreleri takip etmek amacıyla son sütuna virus inokulasyonu yapılmadı. Virus inkübasyonunu takiben pleyt gözleri fosfat tamponlu tuz çözeltisi (PBS) ile üç defa yıkandı. Daha sonra enfekte hücrelerin bulunduğu her kolona $1 \mathrm{ml}$ non-sitotoksik konsantrasyonda (sırasiyla 0,1 ve $2,5 \mu \mathrm{M}$ ) IVM ilave edildi ve $37^{\circ} \mathrm{C}$ 'de $\% 5$ $\mathrm{CO}_{2}$ ihtiva eden ortamda inkübe edildi. Enfekte hücreler 8 gün boyunca invert mikroskop altında sitopatojenik değişiklikler açısından incelendi. PPRV'nin sitopatojenik etkilerinin Vero hücrelerinde 4. günden itibaren gözlenmesi nedeniyle bu zaman noktasindan itibaren her 24 saatte bir (96, 120, 144, 168 ve 192. saatlerde) virusla enfekte hücreler hücre üst sıvısıyla birlikte pipete edilerek toplandı ve $-80^{\circ} \mathrm{C}$ 'de donduruldu. Virus titrasyon testi öncesinde ilgili tüpler $37^{\circ} \mathrm{C}$ 'de çözdürüldü ve 10 dakika 3000 rpm'de santrifüj edildi. Santrifüj sonrası elde edilen süpernatantlara virus titrasyon testi uygulanarak virusun enfektif gücünün tayini yapildı.

PPRV'nin hücreye tutunma aşamasında ivermektinin antiviral etkisinin belirlenmesi

IVM'nin PPR virusunun hücre içi çoğalması esnasındaki antiviral etkinliğinin değerlendirilmesinin ardından, replikasyonun erken aşamalarındaki etkisini de değerlendirmek için hücreye tutunma (adsorbsiyon) ve hücreye giriş (entry, penetrasyon) aşamalarındaki virus ile IVM muamele edildi. Test prosedürü kapsamında hedef hücreye bağlanma aşamasındaki PPR virusuna karşı IVM'nin antiviral etkinliğini değerlendirmek için hücre kültürüne inokule edilmeden önce virus ile IVM muamele edildi ${ }^{18}$. $\mathrm{Bu}$ amaçla, testten 24 saat önce 24 gözlü pleytler Vero hücreleri ile kaplandı. Takip eden günde ise ilk aşama olarak, virus 100DKID50 oranında sulandırıldı. Son sulandırma basamağında IVM'nin test edilmesi için 2,5 $\mu \mathrm{M}$ IVM içeren DMEM kullanılırken, kontrol testi için IVM içermeyen DMEM kullanıldı. IVM ile muamele edilen ve edilmeyen virus sulandırmaları eş zamanlı olarak $37^{\circ} \mathrm{C}$ 'de 1 saat boyunca inkübe edildi ve süre sonunda Vero hücrelerine virus süspansiyonlarından $200 \mu \mathrm{l}$ hacimde inokule edildi. Pleytler $4^{\circ} \mathrm{C}$ 'de 1 saat inkübasyonu takiben bağlanmamış virus partiküllerini uzaklaştırmak için test gözleri üç kez PBS ile yıkandı. Hücrelere IVM ve FDS içermeyen $1 \mathrm{ml}$ DMEM ilave edildi ve IVM ile muamele edilmeyen virus kontrol hücrelerinde $>\% 80$ sitopatojenik etki gelişene kadar pleytler $37^{\circ} \mathrm{C}$ 'de $\% 5 \mathrm{CO}_{2}$ içeren koşullarda inkübe edildi. Virus ekimi sonrası 7. günde dondurularak toplanan enfekte hücreler üst sıvılarıyla birlikte virus titrasyon testine kadar $-80^{\circ} \mathrm{C}$ 'de sakland1.

\section{PPRV'nin hücreye giriş aşamasında ivermektinin anti- viral etkisinin belirlenmesi}

Testten bir gün önce 24 gözlü pleytlerde Vero hücreleri (8x104 hücre/ml) hazırlandı. PPRV'nin Vero hücrelerine giriş aşamasında IVM'nin antiviral etkinliğini belirlemek için ilk olarak virusa hücreye girmesi için bir süre tanındı. $\mathrm{Bu}$ amaçla, PPR virus stoğu $100 \mathrm{DKID}_{50}$ oranında sulandırıldı ve 24 gözlü pleytlerdeki her bir göze virus süspansiyonundan $200 \mu \mathrm{l}$ inokule edildi. Pleytler $4^{\circ} \mathrm{C}$ 'de 2 saat inkübe edildi ve süre sonunda hücreler üç defa PBS ile yıkandı. Daha sonra enfekte hücrelere 2,5 $\mu \mathrm{M}$ IVM ihtiva eden $500 \mu \mathrm{l}$ DMEM eklendi ve $37^{\circ} \mathrm{C}$ 'de 1 saat inkübe edildi. Eş zamanlı olarak virus kontrol amacıyla hazırlanan enfekte edilmiş hücrelere IVM ve FDS içermeyen $500 \mu \mathrm{l}$ DMEM eklendi. Daha sonra hala tutunma fazında olan virus partiküllerini uzaklaştırmak amacıyla enfekte hücre yüzeyleri PBS ( $\mathrm{pH}$ 3,00) ile 3 defa yıkandı. Tüm pleyt gözlerine IVM ve FDS içermeyen $1 \mathrm{ml}$ DMEM ilave edildi. Virus kontrol gözlerinde $>\% 80$ sitopatojenik etki gelişene kadar $37^{\circ} \mathrm{C}$ de \%5 CO2 atmosferik koşullar altında inkübe edildi. Virus ekimini takiben 7. günde enfekte hücreler ve hücre üst sıv1si birlikte toplanarak virus titrasyon testine kadar $-80^{\circ} \mathrm{C}$ de saklandi.

\section{Virus titrasyon testi}


IVM'nin virus üremesini inhibe edip etmediğini değerlendirmek amaciyla test uygulamalarında toplanan viruslara enfektif güç tayini mikrotitrasyon yöntemiyle yapıldı. Bu amaçla, non-sitotoksik konsantrasyonlardaki IVM ile muamele edilen ve edilmeyen PPRV ile enfekte hücrelerin eş zamanlı olarak viral titreleri $\left(\mathrm{DKID}_{50} / 0,1 \mathrm{ml}\right)$ karşılaştırıldi. Virus titreleri, DMEM içerisinde 10 katlı olarak (Log $\left.{ }_{10}\right)$ seri sulandırma yöntemi kullanılarak belirlendi. Test protokolünde, her bir virus sulandırma basamağ i için 96 gözlü mikropleytlerde dört paralel sütun kullanıldı ve sulandırma basamaklarından ilgili gözlere $100 \mu \mathrm{l}$ virus dilusyonlarından aktarıldı. Ayrıca testin kontrolü amaciyla her test pleytinde dört pozitif (sulandırılmamış saf virus ekimi yapılan) ve dört negatif (virus ekimi yapılmayan) test gözü kullanıldı. Tüm test gözlerine $50 \mu \mathrm{l}$ Vero hücre süspansiyo$\mathrm{nu}(15 \times 104$ hücre $/ \mathrm{ml})$ eklendi ve pleytler $37^{\circ} \mathrm{C}^{\prime}$ de $\% 5 \mathrm{CO}_{2}$ ortamında inkübe edildi. Pleytler, sitopatojenik etki gelişimini takip etmek için invert mikroskop altında günlük olarak kontrol edildi. DKID ${ }_{50}$ değerleri, Spearman-Kârber yöntemi kullanılarak hesapland. IVM ile muamele sonucunda elde edilen virus inhibisyon oranının hesaplanması formül $(\%$ inhibisyon $=[(D 0-D 1) / D 0] \times 100)$ uygulanarak yapıldı. Bu formülde D0: IVM ile muamele edilmeyen $(0 \mu \mathrm{M})$ enfeksiyöz virionların 10X0 DKID $_{50}$ sayısal değerini, D1: IVM ile muamele edilen (1 ve 2,5 $\mu \mathrm{M})$ virusun enfeksiyöz virionların $10 \mathrm{X} 1 \mathrm{DKID}_{50}$ sayısal değerini ifade etmektedir.

\section{İstatistik analizler}

Tüm deney aşamaları çalışma sürecinde iki kez tekrarland. Sonuçlar, IBM SPSS Statistic 23 programı kullanılarak analiz edildi. IVM muamelesi yapilan test gruplarının ortalama viral titre $\left(\mathrm{DKID}_{50} / 0,1 \mathrm{ml}\right)$ değerleri ile virus kontrol titre değerlerini karşılaştırmak için verilere bağımsız örneklem T-testi uygulandı. İstatistiksel anlamlılık düzeyi $\mathrm{P}<0,05$ olarak tanımland 1 .

\section{Bulgular}

Vero hücrelerinde non-sitotoksik ivermektin konsantrasyonları

Vero hücrelerinde sitotoksik olmayan IVM konsantrasyonlarını belirlemek için, IVM ile muamele edilen hücrelerin canlılık oranları sekiz gün (192 saat) boyunca günlük olarak kayıt altına alındı. 10 ve 7,5 $\mu$ M IVM konsantrasyonlarında 2. günden itibaren, $5 \mu \mathrm{M}$ IVM konsantrasyonu ise 4 . günden itibaren Vero hücrelerinde sitotoksik etki geliştiği tespit edildi. Deneyin 192. saatindeki hücre canlılı̆ğ oranları, IVM ile muamele edilmeyen hücre kontrol gözünde $(0.0 \mu \mathrm{M}) \% 86,89$ iken, 1,$0 ; 2,5 ; 5,0 ; 7,5$ ve 10,0 $\mu \mathrm{M}$ IVM için sirasiyla $\% 90,00 ; \% 86,96 ; \% 0,0 ; \% 0,0$ ve $\% 0,0$ olarak belirlendi (Şekil 1). Bu nedenle, PPRV’ye karşı IVM’nin antivi- ral aktivitesini değerlendirmek için sitotoksik olmayan 1,0 $\mu \mathrm{M}$ ve 2,5 $\mu \mathrm{M}$ IVM konsantrasyonları seçildi (Şekil 2).

\section{PPRV replikasyonunun ivermektin ile inhibisyonu}

PPRV'nin in vitro replikasyonuna karşı IVM’nin antiviral

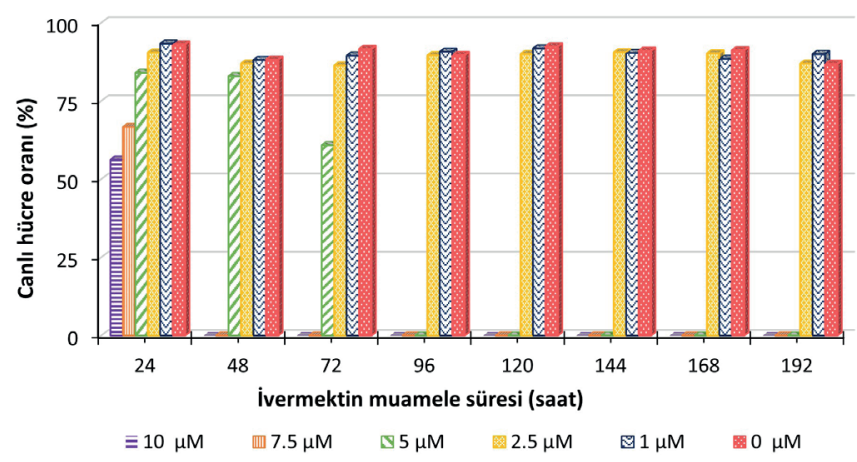

Şekil 1. Çeşitli ivermektin konsantrasyonları ile muamele edilen Vero hücrelerinin canlılık oranları (\%).

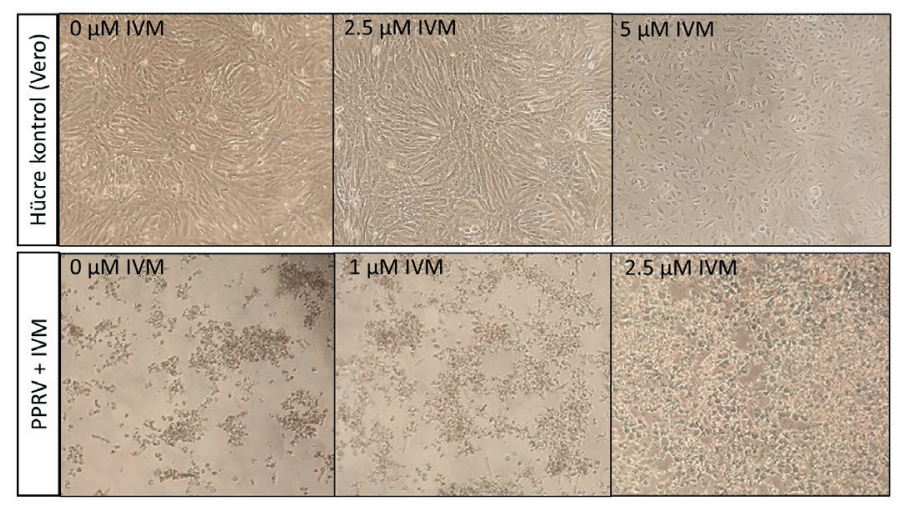

Şekil 2. Farklı konsantrasyonlarda ivermektin ilavesinin PPR virusu üremesi üzerine etkisi (192. saat) (10x20 büyütme). $0.0 \mu \mathrm{M}$, IVM ile muamele edilmeyen Vero hücresini ifade etmektedir. 2.5 $\mu \mathrm{M}$ IVM uygulamaları Vero hücresi için non-sitotoksik IVM konsantrasyonu olarak belirlenmiştir. $5 \mu \mathrm{M}$ IVM ile muamele edilen Vero hücrelerinde sitotoksik değişiklikler gözlenmektedir.

PPRV: Peste des petits ruminants virus; IVM: İvermektin

etkinliğini değerlendirmek amacıyla 8 gün boyunca $1 \mu \mathrm{M}$ ve 2,5 $\mu \mathrm{M}$ IVM ile muamele edilen ve edilmeyen PPRV ile enfekte edilmiş hücrelerdeki viral titre seviyeleri karşılaşt1rıldı. PPRV'nin sitopatojenik etkilerinin Vero hücrelerinde 4. günden itibaren başlaması nedeniyle virus titrasyon testi, 4. ve 8. günler arasında belirlenmiş zaman dilimlerinde (enfeksiyon sonras1 96, 120, 144, 168 ve 192. saatlerde) yapıldı (Şekil 2). PPRV'nin ortalama viral titresi 192. saatte, virus kontrol gözünde $\left(0 \mu \mathrm{M}\right.$ IVM) 4,25 $\log _{10} \operatorname{DKID}_{50} / 0,1$ $\mathrm{ml}$ iken, $1 \mu \mathrm{M}$ ve $2,5 \mu \mathrm{M}$ IVM ile muamele edilen gözlerde sirasiyla $4,13 \log 10$ ve $3,13 \log _{10} \operatorname{DKID}_{50} / 0,1 \mathrm{ml}$ olarak belirlendi. $1 \mu \mathrm{M}$ ve $2,5 \mu \mathrm{M}$ IVM varlığında, 192 . saatteki enfeksiyöz virionların sayısal olarak sırasıyla $\% 25,01$ ve \%92,50 oranında inhibe olduğu hesaplandı (Şekil 3). Farklı dozlarda IVM ile muamele edilen PPRV'nin viral titrele- 
rindeki değişiklikler dikkate alındığında, yalnızca 2,5 $\mu \mathrm{M}$ IVM ile tedavi verilerinde istatistiki olarak anlamlı düzeyde viral titre düşüşü olduğu saptandı $(\mathrm{P}<0,05)$.

\section{Virusun hücreye tutunma ve girişi aşamalarında iver-} mektinin antiviral etkisi

Hücreve tutunma ve hücreye giris așamalarında PPRV've

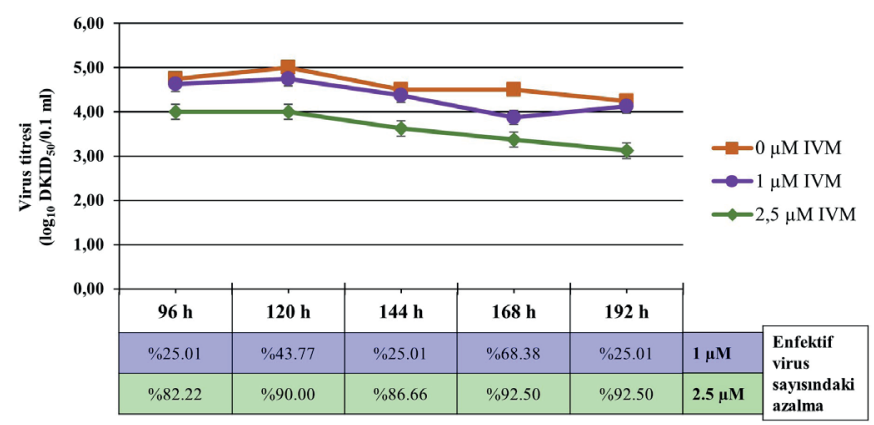

Şekil 3. PPRV ile enfekte Vero hücre kültürlerinde non-sitotoksik IVM konsantrasyonları $(0,1$ ve $2,5 \mu \mathrm{M})$ ile muamele sonrası virus titrelerinin zamana bağlı değişimi.

karşı IVM'nin antiviral aktivitesi farklı test prosedürleri uygulanarak değerlendirildi. Bu amaçla, kontrol virusunun (IVM ile muamele edilmeyen) ve sitotoksik olmayan en yüksek IVM dozu ile $(2,5 \mu \mathrm{M})$ muamele edilen PPRV'nin titreleri, virus ekiminden sonraki 7. günde titrasyon testi aracılığıyla karşılaştırıldı. IVM'nin hücreye tutunma aşamasındaki PPRV'ye karşı etkili bir antiviral aktiviteye sahip olmadığı (\%0,0 inhibisyon) saptandı. Hücreye giriş aşamasında ise PPRV için saptanan ortalama titre değeri virus kontrol gözünde $\left(0 \mu \mathrm{M}\right.$ IVM) 5,00 $\log _{10} \mathrm{DKID}_{50} / 0,1 \mathrm{ml}$ iken, 2,5 $\mu \mathrm{M}$ IVM varlığında 4,63 $\log _{10}$ DKID $_{50} / 0,1 \mathrm{ml}$ olarak belirlendi. Ortalama viral titre değerindeki düşüşe bağlı olarak virusun enfektivite gücünün $\% 57,83$ oranında azaldığı saptandı.

\section{Tartışma ve Sonuç}

Koyun ve keçilerin oldukça bulaşıcı ve ekonomik açıdan önemli bir viral enfeksiyonu olan küçük ruminant vebası, OIE tarafindan kara hayvanlarının bildirimi zorunlu bir hastalığı olarak sınıflandırılmaktadır. Aşılama PPR’ye karş1 koruma ve kontrol amaciyla uygulanan en etkili yoldur. Bununla birlikte, enfeksiyona yakalanan duyarlı hayvanları tedavi etmek için etken üzerine doğrudan etkili bir antiviral ilaç bulunmamaktadır. IVM, insanlar ve hayvanlar için FDA (Food and Drug Administration) onaylı ve yaygın olarak kullanılan geniş spektrumlu antiparaziter bir ilaçtır. Son ylllarda IVM'nin importin $\alpha / \beta$ inhibisyonu aracıllğıyla viral proteinlerin konak hücre çekirdeğine taşınmasını engellediği bildirilmiştir ${ }^{11,12}$. IVM'nin bu aktivitesinin keşfi birçok virus üzerinde antiviral etkinliğinin değerlendiril- mesine yönelik çalışmaların önünü açmıştır.

$\mathrm{Bu}$ çalışmada, PPRV'nin hedef hücreye tutunma, giriş ve viral replikasyon aşamalarında Vero hücrelerinde sitotoksik olmayan IVM konsantrasyonlarının PPRV'ye karşı antiviral etkinliği değerlendirilmiştir. Bu amaçla ilk olarak IVM'nin Vero hücrelerindeki sitotoksisitesi, canlı hücre sayılarının toplam hücreye yüzdesel oranı hesaplanarak belirlendi. Bunun sonucunda, $5 \mu \mathrm{M}$ ve üzeri IVM konsantrasyonlarının Vero hücreleri için sitotoksik olduğu saptandi. Daha önceki çalışmalarda IVM, Vero/hSLAM hücre hattında $5 \mu \mathrm{M}$, MDBK hücre hattında $5 \mu \mathrm{M}$ ve 25 $\mu \mathrm{M}, \mathrm{BHK}-21$ hücre hattında $0,6 \mu \mathrm{M}$ ve $3 \mu \mathrm{M}$, primer civciv hücre kültüründe $50 \mu \mathrm{M}$ ve PK-15 hücre hattında $100 \mu \mathrm{g} /$ $\mathrm{ml}$ olmak üzere farklı hücre hatları ve konsantrasyonlarda güvenle kullanılmıştır ${ }^{12,13,15,18-21}$. Güvenli uygulama dozlarındaki bu çeşitlilik hücre hatlarının biyolojik döngüsündeki farklılıklardan kaynaklanabileceği gibi deney ve laboratuvar koşullarındaki değişiklikler nedenli de olabilir. Bu çalışmada IVM'nin PPR virusunun hücre içi replikasyonu aşamasında antiviral etkinliğe sahip olup olmadığını değerlendirmek için virusla enfekte Vero hücreleri farklı konsantrasyonlardaki ( $1 \mu \mathrm{M}$ ve $2,5 \mu \mathrm{M}$ ) IVM çözeltileri ile muamele edildi. Elde edilen bulgular 2,5 $\mu \mathrm{M}$ IVM varlığında PPRV'nin ortalama viral titre değerinde yaklaşı 1,12 $\log _{10} \mathrm{DKID}_{50} / 0,1 \mathrm{ml}$ düzeyinde istatistiki olarak da anlamlı $(\mathrm{P}<0,05)$ bir azalma olduğunu ve buna bağlı olarak virus replikasyonunda yaklaşık \%92,50 oranında inhibisyon meydana geldiğini göstermektedir. Daha önceki çalışmalar IVM'nin birkaç DNA virusu yanısıra ${ }^{18-20}$, HIV-1, Batı Nil virusu, dang humması virusu, zika virus, tick-borne encephalitis virus, bovine viral diarrhea virus, şap virusu, newcastle hastalığı virusu, küçük ruminant vebası virusu, bovine respiratorik sinsitial virus, bovine parainfluenza virus tip 3, bovine coronavirus ve Sars-CoV-2 gibi RNA viruslarında viral replikasyonu belirli düzeyde inhibe ettiğini ortaya koymuştur ${ }^{12-18}$. Ayrıca IVM ile tedavi sonucunda Paramyxoviridae ailesi içerisinde yer alan bovine parainfluenza virus tip 3 (Respirovirus cinsi) viral tiresinde 2 katlı bir azalma bildirilirken ${ }^{18}$, Newcastle hastalığ (Orthoavulavirus cinsi) için ise yalnızca sitotoksik dozlarda güçlü antiviral etki varlığ rapor edilmiştir ${ }^{13}$. Sonuç olarak bu veriler, IVM'nin muhtemelen hem RNA hem de DNA viruslarına karşı geniş bir antiviral aktivitesi olduğunu göstermektedir.

Afzal ve ark. ${ }^{16}$, IVM'nin penetrasyon sonrası dönemde uygulandığında PPRV titresinde 2,5 $\log _{10}$ oranında bir azalmaya neden olduğunu bildirmiştir. Bu çalışmada elde edilen veriler benzer nitelikteki deney düzeninde IVM'nin PPRV üzerine in vitro antiviral etkinliğini teyit etmektedir. Buna mukabil bu çalışmada belirlenen etki düzeyi (viral titrede 1,12 $\log _{10}$ azalma) Afzal ve ark. ${ }^{16}$ tarafından bildi- 
rilen değerlerin altında bulunmuştur. Bu farklılığın olası nedenlerinden biri Afzal ve ark. ${ }^{16}$ nın çalışmalarında DMSO’da çözdürülmüş saf ivermektin preparatı kullanılması olabilir.

PPRV replikasyonunun erken aşamasında IVM'nin antiviral etkinliğini değerlendirmek için hücreye tutunma ve giriş aşamalarında virus ile IVM muamele edilerek hücrede enfeksiyon başlatıldı. PPRV'nin hücreye tutunma aşamasında IVM'nin antiviral etkisi olmadığ $\breve{1}(\% 0,0$ inhibisyon) görülürken, hücreye giriş aşamasında $2,5 \mu \mathrm{M}$ IVM varlığında virusun enfektivite gücünde $\% 57,83$ oranında azalma olduğu belirlendi $\left(0,37 \log _{10} \mathrm{DKID}_{50} / 0,1 \mathrm{ml}\right.$ düzeyinde düşüş; $P>0,05)$. Söz konusu veriler replikasyon aşamasındaki veriler ile kıyaslandığında, IVM’nin PPRV'ye karşı antiviral etkinliğinin viral replikasyonun ileri aşamalarında daha belirgin olduğu görülmektedir. Daha önceki çalışmalarda, yalancı kuduz virusu ${ }^{19}$, bazı flaviviruslar ${ }^{14}$, bovine coronavirus, bovine viral diyare virus, bovine parainfluenza virus tip 3, bovine respiratorik sinsitial virus ${ }^{18}$ ve bovine herpesvirus tip $1^{\prime}$ in $^{18,20}$ hedef hücreye tutunma ve hücreye giriş aşamaları üzerinde IVM’nin antiviral etkisi olmadığg gösterilmiştir. Bu çalışmanın bulguları ile literatür verileri uyumlu olarak, ivermektinin viral replikasyonun erken aşamalarını etkilemediğine işaret etmektedir.

$\mathrm{Bu}$ çalışmadan elde edilen veriler ışı̆̆ında, IVM'nin bir anti-PPRV ilacı olma potansiyeline sahip olduğu ve bu hastalığın kontrolüne ve tedavisine yardımcı olabileceği ortaya konulmuştur. IVM’nin PPRV'ye karşı olan antiviral etkinliğinin virus replikasyonunun geç aşamalarında daha etkili olduğu öngörülmektedir. IVM'nin in vitro olarak virus replikasyonuna inhibitör etkisini teyit edebilmek ve terapötik etkinliğini belirleyebilmek için in vivo çalışmalarla desteklenmesi yararlı olacaktır.

\section{Teşekkürr}

Dr. E.B. Toker, Türkiye Bilimsel ve Teknolojik Araştırma Kurumu tarafından doktora sonrası araştırmacı olarak desteklenmektedir (TÜBİTAK, Proje No: 119 O 571). Peste des petits ruminants virusunun temin edilmesi aşamasındaki yardımları için VETAL Hayvan Sağlı̆̆ Ürünleri A.Ş.'ye (Adıyaman, Türkiye) teşekkür ederiz.

\section{Kaynaklar}

1. OIE. Peste des Petits Ruminants. The Center for Food Security \& Public Health. 2015:1-5. https://www.cfsph. iastate.edu/. (Erişim tarihi: 02.12.2021).

2. Jones BA, Rich KM, Mariner JC, et al. The economic impact of eradicating peste des petits ruminants: A benefit-cost analysis. PLoS ONE. 2016;11(2). doi:10.1371/journal.pone.0149982

3. OIE, FAO. Global Strategy for the Control and Eradi- cation of PPR.; 2015. (Erișim tarihi: 02.12.2021).

4. ICTV. Taxonomic Information-International Committee on Taxonomy of Viruses. https://talk.ictvonline.org/. (Erişim tarihi: 02.12.2021).

5. Muniraju M, Munir M, Parthiban AR, et al. Molecular evolution of peste des petits ruminants virus. Emerging Infectious Diseases. 2014;20(12):2023-2033. doi:10.3201/eid2012.140684

6. ViralZone. SIB Swiss Institute of Bioinformatics. https://viralzone.expasy.org/.

7. Baron MD, Parida S, Oura CAL. Peste des petits ruminants: A suitable candidate for eradication? Veterinary Record. 2011;169(1):16-21. doi:10.1136/vr.d3947

8. Kgotlele T, Chota A, Chubwa CC, et al. Detection of peste des petits ruminants and concurrent secondary diseases in sheep and goats in Ngorongoro district, Tanzania. Comparative Clinical Pathology. 2019;28(3):755-759. doi:10.1007/s00580-018-2848-5

9. Zhao H, Njeumi F, Parida S, et al. Progress towards eradication of peste des petits ruminants through vaccination. Viruses. 2021;13(1):1-15. doi:10.3390/ v13010059

10. Campbell WC, Fisher MH, Stapley EO, et al. Ivermectin: a potent new antiparasitic agent. Science. 1983;221(4613):823-828. doi:10.1126/science.6308762

11. Wagstaff KM, Sivakumaran H, Heaton SM, et al. Ivermectin is a specific inhibitor of importin $\alpha / \beta$-mediated nuclear import able to inhibit replication of HIV-1 and dengue virus. Biochemical Journal. 2012;443(3):851856. doi:10.1042/BJ20120150

12. Yang SNY, Atkinson SC, Wang C, et al. The broad spectrum antiviral ivermectin targets the host nuclear transport importin $\alpha / \beta 1$ heterodimer. Antiviral Research. 2020;177:104760. doi:10.1016/j.antiviral.2020.104760

13. Azeem S, Ashraf M, Rasheed MA, et al. Evaluation of cytotoxicity and antiviral activity of ivermectin against Newcastle disease virus. Pakistan Journal of Pharmaceutical Sciences. 2015;28(2):597-602.

14. Mastrangelo E, Pezzullo M, De Burghgraeve T, et al. Ivermectin is a potent inhibitor of flavivirus replication specifically targeting NS3 helicase activity: New prospects for an old drug. Journal of Antimicrobial Chemotherapy. 2012;67(8):1884-1894. doi:10.1093/ jac/dks147

15. Caly L, Druce JD, Catton MG, et al. The FDA-approved drug ivermectin inhibits the replication of SARS-CoV-2 in vitro. Antiviral Research journal. 2020;178:104787.

16. Afzal S, Raza S, Rabbani M, et al. Antiviral Potential of Ivermectin against Peste des Petits Ruminants Virus 
(PPRV). Pakistan J Zool. 2021:1-4. doi:10.17582/journal.pjz/20200704060712

17. Naeem Z, Raza S, Afzal S, et al. Antiviral potential of ivermectin against foot-and-mouth disease virus, serotype O, A and Asia-1. Microbial Pathogenesis. 2021;155:104914. doi:10.1016/j.micpath.2021.104914

18. Yesilbag K, Toker EB, Ates O. Ivermectin also inhibits the replication of bovine respiratory viruses (BRSV, BPIV-3, BoHV-1, BCoV and BVDV) in vitro. Virus Research. 2021;297:198384. doi:10.1016/j.virusres.2021.198384

19. Lv C, Liu W, Wang B, et al. Ivermectin inhibits DNA polymerase UL42 of pseudorabies virus entrance into the nucleus and proliferation of the virus in vitro and vivo. Antiviral Research. 2018;159:55-62. doi:10.1016/j.antiviral.2018.09.010

20. Raza S, Shahin F, Zhai W, et al. Ivermectin inhibits bovine herpesvirus 1 DNA polymerase nuclear import and interferes with viral replication. Microorganisms. 2020;8(3):1-15. doi:10.3390/microorganisms8030409

21. Varghese FS, Kaukinen P, Gläsker S, et al. Discovery of berberine, abamectin and ivermectin as antivirals against chikungunya and other alphaviruses. Antiviral Research. 2016;126:117-124. doi:10.1016/j.antiviral.2015.12.012 